A N N A L E S

UNIVERSITATIS M A R A E C URIE-SKŁODOW S A

LUBLIN - POLONIA

VOL. XXXII, 1

SECTIO J

2019

Ternopil Volodymyr Hnatiuk National Pedagogical University

\title{
HANNA SLOZANSKA
}

ORCID ID: https://orcid.org/0000-0002-8394-4925

kulynyak@elr.tnpu.edu.ua

NADIA HORISHNA

ORCID ID: https://orcid.org/0000-0002-9724-7098

nadiahorishna@yahoo.com

OKSANA PRYSHLYAK

ORCID ID: https://orcid.org/0000-0003-3108-502X

pryshlyak_o@yahoo.com

\section{The Modern State of Social Workers' Training in Ukrainian Higher Educational Institutions to Work in the Territorial Communities}

\footnotetext{
Współczesny stan przygotowania pracowników socjalnych kształcących się w ukraińskich szkołach wyższych do pracy w społecznościach terytorialnych
}

\section{STRESZCZENIE}

Reorientacja pracy społecznej na poziomie lokalnym świadczenia usług socjalnych, odbywająca się na Ukrainie w wyniku reformy decentralizacji władzy, aktualizuje przygotowania pracowników socjalnych do pracy w danej społeczności. W artykule przedstawiono aktualny stan rozwoju i wdrażania programów edukacyjnych ze specjalizacją w pracy socjalnej w społeczności na różnych poziomach szkolnictwa wyższego. Wyniki badań wykazały, że instytucje szkolnictwa wyższego nie były przygotowane na szybkie reagowanie na publiczne prośby o szkolenie specjalistów w zakresie pracy socjalnej w zjednoczonych społecznościach terytorialnych. Ustalono, że w 2017 r. możliwość uzyskania specjalizacji w pracy socjalnej w społeczności oferował tylko jeden program edukacyjny na studiach licencjackich i cztery na studiach magisterskich. Przeanalizowano straty i korzyści ukraińskich instytucji szkolnictwa wyższego wynikające z wdrażania takich programów. Zrozumienie istniejącyh barier, a także możliwości, jakie instytucje szkolnictwa wyższego odnoszą z wdrażania 
programów pracy socjalnej we wspólnotowej pracy socjalnej, jest niezbędne do określenia celowych oraz do prowadzenia systematycznych wspólnych działań na rzecz rozwoju zawodu, społeczności lokalnych i społeczeństwa jako całości.

Słowa kluczowe: praca socjalna; pracownik socjalny; usługi społeczne; społeczność; zjednoczona wspólnota terytorialna; szkolenie zawodowe pracowników socjalnych; specjalizacja pracy socjalnej w społeczności

\section{SUMMARY}

Refocusing of social work at the local level of social services provision that is taking place in Ukraine now, as a result of reform of decentralization of authority, actualizes the question of training social workers to work in the community. The article discloses the modern state of development and implementation of educational programs with specialization in social work in community at various levels of higher education. The results of the study showed the unwillingness of the higher educational institutions to respond promptly to public requests for social workers training to work in the amalgamated communities. It was established that in 2017, the opportunity to specialize in social work in the community was offered only by one educational program at the undergraduate level and four at the graduate level. The analysis of the obstacles and benefits of Ukrainian higher education institutions in the implementation of such programmes is given. Understanding the existing barriers as well as the opportunities the higher education institutions get from the implementation of social work programs in community social work is necessary for the purposeful and systematic joint activities for the development of the profession, local communities, and society as a whole.

Keywords: social work; social worker; social services; community; amalgamated territorial community; social workers training; specialization in community social work

\section{INTRODUCTION}

In Ukraine, institutionalization of practical social work at the local level takes place under the reform of decentralization of authority (Slozanska 2017, p. 293). The evidence of this is the employment of social workers, able to organize, administer, plan and provide various kinds of social services to vulnerable populations of the amalgamated territorial communities.

Nowadays, social workers employed at the local level have to overcome the consequences of many social phenomena and processes, such as poverty, aging of population, military conflicts, forced migration, spread of various forms of deviancy, etc., the causes of which are global in nature. The activities of these professionals are directed to the development of social work in the amalgamated territorial communities. These can be done through the provision of social services to individuals and/or families in the difficult circumstances, prevention and solving of social prob- 
lems, consulting and informing on a wide variety of social and community services, arrangement of social activities, fostering of communication, cooperation and partnership with different social institutions within and beyond the community. For the effective discharge of their duties, social workers must not only have a set of common knowledge and skills, but also some specific competences.

According to official data (Monitorynh protsesu detsentralizatsii vlady ta reformuvannia mistsevoho samovriaduvannia, 2018), as of August 2018, 803 amalgamated territorial communities were established in the course of decentralization reform. In 184 amalgamated territorial communities, their own municipal social agencies have been founded; 739 new positions of social workers have been introduced. In 662 amalgamated territorial communities, social services are being provided by the city and/or district social agencies under the concluded agreements; they employ 698 social workers. In addition, in 71 amalgamated territorial communities, Children's Services have been founded, in others the authority to protect children's rights has been delegated to 372 appointed officials. In future, such services must be established in all communities, and the corresponding positions can be occupied by professionals who hold social work degrees.

It is worth noting that social work positions has considerable potential for growth. This prediction is based on the following factors:

- not in all amalgamated communities the number of social work positions meets the standards ( 1 social worker per 1,000 population of rural areas);

- one third of the amalgamated territorial communities (403) of their scheduled amount $(1,206)$ is not yet formed;

- potentially social workers at the community level, can be employed not only by state and municipal, but also by non-governmental and private social agencies. These data indicate that territorial community is one of the most important and promising areas of social work practice. Therefore, the introduction of specializations related to the community work in social work degree programs is considered as an adequate response to the demands of society, professional practice and labour market.

It should be noted that Ukrainian legislation provides for training in specializations within all specialties and fields of study and at all levels of higher education. In particular, according to the Law "On Higher Education", higher educational institutions (HEIs) within a licensed specialty can develop and implement educational programs with specializations. Specialization is considered as a component of specialty, which is determined by the HEI and involves a specialized professional or scientific program of training (Law of Ukraine "On Higher Education", 2018). To provide training in specialization, the HEI implements the educational program, the name of which coincides with the name of the specialization. The educational program of specialization must ensure compliance with the Standard of Higher Education in the specialty. 
In this respect, it must be noted that to date in Ukraine the state standards on higher education in social work have not been approved at none of the levels of higher education. On the one hand, it hinders the unification of the content of social workers training, its continuity at the higher levels, the introduction of uniform competencies for graduates of social work degree programs at the particular level of higher education. On the other hand, it gives HEIs a free hand to develop educational programs in specializations and to determine their content.

Despite the fact that nowadays in Ukraine there are no clear requirements to the content and learning outcomes of social work degree programs as well as there is no approved list of specializations within a licensed specialty, there are still certain general requirements to organization of educational process, the number of credits, program's staff and infrastructure and other resourses. Such general requirements are defined in the Law of Ukraine "On Higher Education" (2018) and the Resolution of the Cabinet of Ministers of Ukraine "On Approval of Licensing Conditions for Educational Activities" (2015). Each HEI develops educational programs based on the needs for professionals in a particular field of expertise, existing staff, material and technical resources; licenses and accredits it. The authority conducting licensing of educational programs is the Ministry of Education and Science of Ukraine. It issues licenses for educational activity on the basis of positive expert opinion of the National Agency for Quality Assurance in Higher Education. The compliance of level of training within licensed specialties with the Standard of Higher Education and the ability to meet the requirements of the standard and achieve program's learning outcomes are determined through the accreditation procedure (Article 1 of the Law of Ukraine "On Higher Education", 2018).

A public authority given the power to accredit educational programs is the National Agency for Quality Assurance in Higher Education. This agency also creates a single database of implemented by HEIs specializations. Despite the fact that the establishment of the National Agency for Quality Assurance in Higher Education was provided by the Law of Ukraine "On Higher Education", which came into force on 6 September 2014, to date such a body is still nonexistent.

Thus, in the absence of data on social work degree programs with specialization in community work, we undertook a study to gather information about them and to identify the barriers to and benefits of their implementation.

\section{LITERATURE REVIEW}

The scientific works of O. Bezpalko (2006), and T. Semyhina (2004) provided the basis for our research. Semyhina was the first among Ukrainian researchers who carried out the analysis of the main approaches to the definition of the terms "community" and "territorial community". She described the peculiarities 
of community social work abroad and elucidated the role of social worker and public participation in community life (Semyhina 2004).

A significant contribution to the development of social work in the community has made Bezpalko. The researcher considers social work in community as "one of the levels of social work that is carried out using appropriate forms and methods". She substantiated theoretical, organizational and methodological basics of socio-pedagogical work with children and youth in community; defined the role of local communities in development and formation of personality; revealed the essence of socio-pedagogical work in community and its peculiarities; carried out a retrospective analysis of development of socio-pedagogical work with children and young people in community; described the functions of social workers, working with children and youth at the local level (Bezpalko 2006).

However, it should be noted that in works of both Semyhina and Bezpalko, community social work is being primarily considered as an activity of the social worker with people who have common interests, views, desires, and ideas. However, today the perception of community as an association of citizens living in a specific geographically defined territory is more relevant to us. Of particular interest are social work efforts for community-based service delivery.

Publications (articles, notes, announcements, programs, presentations, etc.) of such foreign scholars as T. Zolotareva, M. Mynyhalyeva (2001), M. Romm, T. Romm (1999), L. Walter (1997) indexed in the largest scientometric database Google Scholar have not escaped our attention. The total amount of publications devoted to the peculiarities of community social work and social workers training analyzed by the authors is more than 1,000 works.

The issue of place and role of territorial community in the system of local self-government in Ukraine has become a matter studied by domestic (Drobush 2014; Zhovnirchyk 2005; Koltsova 2008; Moroz 2008; and others) and foreign scholars (Mayo 2002; Popple 1995; Twelvetrees 1982; Thomas 1983; and others).

The issues related to social workers training have been studied by many Ukrainian scientists. In particular, more than 60 academic theses on social workers training have been done in Ukraine. Due to the diversity of research, they are divided into 4 blocks: dissertations devoted to: 1) the studying of social workers training abroad (in Australia (Slozanska 2011), Great Britain (Pichkar 2002), Canada (Haiduk 2005; Mykytenko 2006), Scandinavian countries (Logvinenko 2015), the USA (Dub 2012; Sobchak 2004), France (Leschuk 2009), etc.) and 2) to work with different categories of clients (elderly people (Golubenko 2015), families (Beloliptseva 2000; Vodyana 2016), children and youth (Petrochko 2011; Zvereva 1998), etc.); 3) the process of personality and professional qualities formation (Kanyuk 2009; Ursol 2012), etc.); 4) the use of active learning methods (Voznyuk 2014), interactive technologies (Melnychuk 2011) in social workers 
training in HEIs, etc. Despite the great interest of Ukrainian scholars in the issue of social workers training, practically no work has been done on their training to work at the community level.

\section{METHODOLOGY}

The purpose of the study was to carry out the analysis of modern state of social workers training in Ukrainian HEIs to community work. The following research questions were posed: 1) How many social work degree programs at different levels of higher education provide training to community work?; 2) What hinders the implementation of such programs and what are the benefits from their implementation?

To answer these questions, we conducted a screening of all social work degree programs, posted on the websites of the HEIs. While analysing the content posted on the sites of the HEIs, we encountered certain difficulties related to the obsolescence, inaccuracy, unreliability of the information presented there. Out of 65 HEIs, providing Bachelor of Social Work (BSW) programs as of December 2015 , only $14(21.5 \%)$ updated information on programs, curricula, and syllabi on their websites; 22 (33.8\%) - renewed it partially (websites lacked accurate and reliable information) and $29(44.7 \%)$ - did not update it at all. Similar was the situation with the Master of Social Work (MSW) programs. In particular, out of 35 HEIs, 14 (40\%) updated information on their websites, 6 (17.1\%) - partially updated it and 15 (42.9\%) - did not do it (Horishna, Slozanska 2017, pp. 169170). As a result, the information we got from the HEIs websites did not provide data to answer the research question.

In the absence of necessary data on the websites, in January 2016, we sent (by e-mail) letters to the heads of social work departments with questions we were interested in. It contained the following questions: 1) Does your institution offer social work degree programs with specialization in community work?; 2) What level of higher education does such program/programs provide?; 3) How many students enrolled and/or graduated these programs?

In December 2017, re-screening of HEIs websites and scientific publications was held to check the availability of social work degree programs with concentration on community work.

\section{RESULTS}

The information posted on the websites of the Ukrainian HEIs, showed that as of December 2015, in Ukraine, there were 65 BSW, 35 MSW (Horishna, Slozanska 2017, p. 169), and 1 Ph.D. program (in School of Social Work of "Kyiv-Mohyla Academy"). The results of HEIs websites screening showed that there were 
no programs on community social work at none of the levels of higher education in Ukraine. The information provided by the electronic survey of the heads of social work departments confirmed the result of screening.

Re-screening of websites and scientific publications conducted in December 2017 demonstrated certain changes in the situation. First, the number of MSW programs has doubled since December 2015; they were implemented by virtually all of the HEIs providing undergraduate education in social work. Secondly, the number of graduate and postgraduate programs in social work increased significantly: 14 HEIs and 1 research institution (Institute of Problems on Education of the National Academy of Pedagogical Sciences of Ukraine) have been issued a license to establish Ph.D. programs. In total, $166 \mathrm{Ph}$.D. students could enroll these programs (Karahodina, Pozhydaieva 2017, p. 86). Thirdly, one undergraduate (at Yuriy Fedkovich Chernivtsi National University) and four graduate programs on community social work have been established. In particular, at Borys Grinchenko Kyiv University (2017) and Ternopil Volodymyr Hnatiuk National Pedagogical University (2017) such programs were called "Social Administration in the Community", at Yuriy Fedkovich Chernivtsi National University (2017) - "Management of Social Processes in the Community". Another MSW program - "Technology and Innovations in Social Work" - implemented in 2017 at the Ukrainian Catholic University in Lviv, as the analysis has shown, has a strong focus on community work. Despite the fact that such orientation of the program was not reflected in its name, we considered it possible to include it into the programs which, among the first in Ukraine, initiated training of social workers to work in community.

\section{DISCUSSION}

Since the official implementation of professional training in the field of social work in Ukraine in 1991, it has passed a long and difficult path of development and continues to evolve. The extension of its spheres, increasing complexity of professional tasks and functions of social workers are the most significant drivers of its development. A striking example of this is the reorientation of social work towards the local level of social services provision which requires from its professionals more advanced and specialized set of skills. If it was impossible for social workers to take a course on community social work earlier, now there is a need to offer a separate concentration in this field.

And, as evidenced by the results of the performed analysis, the first steps in this direction have already been made. Considering that the development and implementation of programs in community social work has been rather slow, we sought it necessary to analyze the barriers and advantages of their introduction.

As the literature analysis shows, Ukrainian scientists have made a significant contribution to the development of theoretical framework of social workers train- 
ing and social work with various categories and groups in the community. However, theory and methodology of training of social workers to work in territorial communities remain undeveloped. It not only slows down the introduction of the relevant specialization, but also reduces the effectiveness of training, narrowing the search for effective methods of building competences in community social work to the trial-and-error method.

Another obstacle is the lack of experience of social workers training in general, and in specializations in particular. In Ukraine until 2014, the training in specializations was formally carried out only for the regulated professions - those for which the procedure of certification and confirmation of professional qualifications are determined by special normative acts. Social work does not belong to such professions. Although, under the new Law of Ukraine "On Higher Education", HEIs received the right to independently determine the specializations and implement them as part of educational programs at the appropriate level of higher education, they do not have the authority to assign professional qualifications, particularly in the case of the unregulated occupations. The situation is complicated by the fact that in the existing Classifier of professions of Ukraine (2010) the description of qualification for "social worker in the community" is not provided. It exists only in a draft form and requires approval at the state level.

A significant obstacle to the implementation of specialization in community social work in Ukrainian HEIs is the disparity between existent staff resources and requirements of the licensing legislation. Most often such problems concern the lack of sufficient number of employees with an academic degree of Doctor of Sciences, and those who have practical experience, the mismatch of teacher's specialty and program's field of study, insufficient amount of teachers' scientific publications and/or manuals. However, the implementation of the new degree programs, especially graduate and postgraduate, indicates positive changes in addressing personnel issues.

Preparing social workers to work in community involves the establishment of close relations with the main stakeholders - potential employers, such as the Executive Committees of the amalgamated territorial communities, social institutions, and public organizations working at the local level. This interaction may be built around such issues as an assessment of needs in social workers and meeting the requirements to their qualification taking into account the specific context of their work, organization of field practice, participation in monitoring and evaluation of the program. Unfortunately, in Ukraine the traditions of stakeholders' engagement in the educational process are not strong due to the short history of both social workers training and existence of amalgameted territorial communities. Despite these limitations, the development and implementation of social work degree programs with community specialization involves certain advantages. 
Today there is no doubt that social work, as an institution of support of people in difficult situations, ensuring decent conditions for their life and development of their personality on the principles of multiculturalism, tolerance, social solidarity, is an important tool for building civil society. In turn, the establishment and development of civil society structures requires qualified personnel. Therefore, the training of social workers, who are able to manage local social agencies and organize social services provision is a significant contribution to the development of Ukrainian civil society.

Despite the public importance of social work, this profession in Ukraine, as in most countries of the world, has a low social status and is not popular among applicants to HEIs. This situation is due to the low prestige of the profession and wages, difficult working conditions, no significant career prospects, social guarantees or employment opportunities. In our opinion, the reform of local government and territorial organization of authority, aimed at the formation of capable territorial communities will create a stable basis for raising the public status of the profession and its level of popularity, primarily among high school graduates from the local communities. The need for professionals, introduction of new social work positions with the prospect of their growth in number, improvement of the image of the profession among the population will allow HEIs to attract more students to social work degree programs with specialization in community work.

The communities' demand for social workers, their involvement as stakeholders in the development and evaluation of educational programs creates opportunities for alternative mechanisms of funding social work degree programs with concentration in community. In addition to budgetary receipts, funds of legal entities and individuals that currently are the main sources of funding of higher education, HEIs will get a real opportunity to attract funds from local budgets, public associations and funds through the conclusion of contracts on provision of educational services (training, professional development, continuous education, scientific research and so forth).

It is obvious that implementation of social work degree programs with concentration in community work in Ukrainian HEIs is constrained by a number of objective factors. The question is whether the advantages from the implementation of such programs worth the effort for overcoming the existing barriers?

\section{CONCLUSIONS}

The relevance of social workers training to work in community nowadays is due to factors such as the delegation of authority in resolving social problems and meeting social needs of the population to local governments, the public demand for quality social services at the local level, the shortage of professionals who have the appropriate education and special training to work in community. 
The implementation of social work degree programs with specialization in community work is appropriate at each level of higher education. In particular, such concentrations at the undergraduate level will provide training to the direct provision of social services, at the graduate level - to the performance of managerial and research tasks, at the postgraduate and doctoral studies level - to the scientific research, development of theoretical foundations of professional activity in community and training of professionals to work in this field.

At the same time, the results of the study showed the unwillingness of the HEIs to respond promptly to public requests for training of social workers to community work. Understanding the existing barriers to the implementation of degree programs with specialization in community social work and the advantages offered to HEIs by their implementation is necessary for the purposeful and systematic joint activities for the development of the profession, local communities, and society as a whole.

\section{REFERENCES}

Bezpalko, O. (2006). Organizacia socialno-pedagogichnoi robotu z ditmu ta moloddu v gromadi [Organization of Social and Pedagogical Work with Children and Youth in the Territorial Community: Theoretical and Methodological Foundations: Monograph]. Kyiv: Nayk. Svit.

Bieloliptseva, O.V. (2000). Pidhotovka sotsialnykh pedahohiv do roboty z simiamy, yaki opynylysia $v$ skladnykh zhyttievykh obstavynakh [Preparation of social teachers for work with families who were in difficult living conditions]: avtoref. dys. na zdob. nauk. stup. kand. ped. nauk: spets. 13.00.05. „Sotsialna pedahohika”. Un-t im. B. Hrinchenka. Kyiv.

Chernivetskyi natsionalnyi universytet imeni Yu. Fedkovycha (2017) [Yuriy Fedkovich Chernivtsi National University]. Mode of access: http://chnu.edu.ua (access: 4.02.2017).

Drobush, I. (2014). Detsentralizatsiia ta subsydiarnist yak neobkhidni umovy realizatsii sotsialnykh prav terytorialnykh hromad na mistsevomu rivni [Decentralization and subsidiarity as a necessary conditions for the implementation of social rights of territorial communities at the local level]. Nacionalnuj jyreduchnuj zyrnal teoria i practuka [National Law Journal of Theory and Practice], 1.

Dub, O.I. (2012). Rozvytok profesiinoi etyky sotsialnykh pratsivnykiv u systemi neperervnoi osvity USA [Development of professional ethics of social workers in the United States Continuing Education System]: dys. kand. ped. nauk: 13.00 .04 „Teoriia i metodyka profesinoi osvity”. Chernih. nats. ped. un-t im. T.H. Shevchenka. Chernihiv, 200.

Haiduk, N.P. (2005). Profesiina pidhotovka sotsialnykh pratsivnykiv do zdiisnennia poserednytstva (na materialakh SShA i Kanady) [Professional training of social workers for mediation (on materials of the USA and Canada)]: dys. kand. ped. nauk: 13.00.04 „Teoriia i metodyka profesiinoi osvity”. Instytut pedahohiky i psykholohii profesiinoi osvity APN Ukrainy. Kyiv, 264.

Holubenko, T.O. (2015). Formuvannia hotovnosti maibutnikh sotsialnykh pratsivnykiv do patronazhnoi roboty z liudmy pokhyloho viku [Formation of readiness of future social workers for patronage work with the elderly]: dys. kand. ped. nauk: 13.00.05 „Sotsialna pedahohika”. Nats. ped. un-t im. M.P. Drahomanova. Kyiv, 250. 
Horishna, N., Slozanska, H. (2017). Dual degree programs in social work: Is it possible in Ukraine? Economics and Sociology, 10. DOI: 10.14254/2071-789X.2017/10-2/12

Kaniuk, O.L. (2009). Formuvannia vmin inshomovnoho dilovoho spilkuvannia maibutnikh sotsialnykh pratsivnykiv $v$ protsesi profesiinoi pidhotovky [The organization of the foreign-language business communication skills formation in the process of future social workers training]: dys. kand. nauk: 13.00.04 „Teoriia i metodyka profesiinoi osvity”. Uzhhorodskyi nats. un-t. Uzhhorod, 227.

Karahodina, O., Pozhydaieva, O. (2017). Zaprovadzhennia prohram pidhotovky doktoriv filosofii z sotsialnoi roboty: analiz potochnoi sytuatsii [Introduction of programs of preparation of doctors of philosophy on social work: analysis of the current situation]. Visnyk Akademii pratsi i sotsialnykh vidnosyn i turyzmu [Journal of the Academy of Labor and Social Relations and Tourism], 1.

Klasyfikator profesij (2010) [Classifier of professions of Ukraine 2010]. Mode of access: https://hrliga.com/index.php?module=norm_base\&op=view\&id=43 (access: 2.08 .2018 ).

Koltsova, D. (2008). Orhany samoorhanizatsii naselennia v systemi mistsevoho samovriaduvannia [Bodies of self-organization of the population in the system of local self-government].

Kyivskyi universytet imeni B. Grinchenka (2017) [Borys Grinchenko Kyiv University]. Mode of access: http://kubg.edu.ua/informatsiya/vstupnikam/pro-universitet.html (access: 2.02.2017).

Leshchuk, H.V. (2009). Systema profesiinoi pidhotovky fakhivtsiv sotsialnoi sfery u Frantsii [System of professional training of specialists in the social sphere in France]: avtoref. dys. na zdobuttia nauk. stupenia kand. ped. nauk : spets. 13.00.04 „Teoriia i metodyka profesiinoi osvity”. Ternopilskyi derzh. pedahohichnyi un-t im. V. Hnatiuka. Ternopil, 20.

Lohvynenko, T. (2015). Pidhotovka sotsialnykh pratsivnykiv v universytetakh Skandynavskykh krain [Social workers training at the universities of the Scandinavian countries]: Daniia, Norvehiia, Shvetsiia. 13.00.04 „Teoriia i metodyka profesiinoi osvity”, Drohobych: Vydavnychyi viddil Drohobytskoho derzhavnoho pedahohichnoho universytetu im. I. Franka.

Mayo, M. (2002). Community work. In: C. Hanvey, T. Philpot (eds.), Practising Social Work. London: Routledge.

Melnychuk, I.M. (2011). Teoriia i metodyka profesiinoi pidhotovky maibutnikh sotsialnykh pratsivnykiv zasobamy interaktyvnykh tekhnolohii u vyshchykh navchalnykh zakladakh [Theory and methodology of future social workers professional training by means of interactive technologies in higher educational institutions]: dys. d-ra nauk: 13.00.04 „Teoriia i metodyka profesiinoi osvity". Ternopilskyi derzh. pedahohichnyi un-t im. V. Hnatiuka. Ternopil, 585.

Monitorynh protsesu detsentralizatsii vlady ta reformuvannia mistsevoho samovriaduvannia (2018) [Monitoring of the process of decentralization of power and reformation of local self-government bodies]. Mode of access: https://decentralization.gov.ua/uploads/library/ file/302/10.08.2018.pdf (access: 12.08.2018).

Moroz, O. (2008). Terytorialna hromada: sutnist stanovlennia ta suchasni ukrainski realii [Territorial community: the essence of formation and modern Ukrainian realities]. Demokratychne vriaduvannia [Democratic Governance], 2.

Mykytenko, N.O. (2006). Profesiina pidhotovka sotsialnykh pratsivnykiv v universytetakh Kanady [Professional training of social workers at the universities of Canada]: dys. kand. ped. nauk: 
13.00.04 „Teoriia i metodyka profesiinoi osvity”. Ternopilskyi nats. ped. un-t im. V. Hnatiuka. Ternopil, 224.

Petrochko, Zh.V. (2011). Teoriia i praktyka sotsialno-pedahohichnoho zabezpechennia prav ditei, yaki opynylysia u skladnykh zhyttievykh obstavynakh [Theory and practice of social and pedagogical provision of children's rights in difficult life situations]: dys doktora ped. nauk: spets. 13.00.05 „Sotsialna pedahohika”. Kyiv, 582.

Pichkar, O.P. (2002). Systema pidhotovky fakhivtsiv sotsialnoi roboty u Velykii Brytanii [System of social workers training in Great Britain]. Olena Pavlivna Pichkar. Uzhhorod, 213.

Popple, K. (1995). Analysing Community Work. UK: McGraw-Hill Education.

Postanova Kabinetu ministriv Ukrainy „Pro zatverdzhennia litsenzijnykh umov provadzhennia osvitnoi diial'nosti" (2015) [Resolution of the Cabinet of Ministers of Ukraine “On Approval of Licensing Conditions for Educational Activities”]. Mode of access: http://zakon.rada.gov.ua/laws/ show/1187-2015-\%D0\%BF (access: 14.07.2018).

Romm, M., Romm, T. (1999). Teoryia sotsyalnoi raboty [Theory of Social Work: A Manual]. Novosybyrsk: NHU.

Semyhina, T. (2004). Robota v hromadi: praktyka y polityka [Work in the Community: Practice and Politics]. Kyiv: Vyd. dim „KM Akademiia”.

Slozanska, H. (2017). Normatyvno-pravove zabezpechennia roboty sotsialnoho pratsivnyka v terytorialnii hromadi [Legislative support of the work of a social worker in a territorial community]. Naukovi poshuky u III tysiacholitti: sotsialnyi, pravovyi, ekonomichnyi ta humanitarnyi vymiry [Scientific Fundamentals In the III Millennium: Social, Legal, Economic and Humanitarian Dimensions]. Kropyvnytskyi: „KOD”.

Slozanska, H.I. (2011). Profesiina pidhotovka sotsialnykh pratsivnykiv u vyshchykh navchalnykh zakladakh Avstralii [Professional training of social workers in higher education institutions in Australia]: dys. kand. ped. nauk: 13.00 .04 ,Teoriia i metodyka profesiinoi osvity”. Ternopilskyi derzh. pedahohichnyi un-t im. V. Hnatiuka. Ternopil.

Sobchak, N.M. (2004). Zmist i formy profesiinoi pidhotovky sotsialnykh pratsivnykiv u systemi neperervnoi osvity USA [The content and forms of social workers training in the United States Continuing Education System]: dys. kand. ped. nauk: 13.00.04 „Teoriia i metodyka profesiinoi osvity”. Ternopilskyi derzh. pedahohichnyi un-t im. V. Hnatiuka. Ternopil, 351.

Ternopilskyj natsionalnyj pedahohichnyj universytet imeni V. Hnatiuka (2017) [Ternopil Volodymyr Hnatiuk National Pedagogical University]. Mode of access: http://npu.edu.ua/about/public_inform/231\%20Sotsialna\%20robota\%20-\%20magister.pdf (access: 6.02.2017).

Thomas, D. (1983). The Making of Community Work. Australia: Allen \& Unwin.

Twelvetrees, A. (1982). What is Community Work? In: A. Twelvetrees (ed.), Community Work. London: Palgrave Macmillan.

Uolter, L. (1997). Sotsyalnaia rabota v yzmeniaiushcheisia Evrope [Social work in a changing Europe]. Sotsyalnaia rabota [Social Work], 4.

Ursol, O.V. (2012). Formuvannia kultury profesiinoho spilkuvannia u maibutnikh sotsialnykh pratsivnykiv zasobamy interaktyvnykh metodiv navchannia [Formation of professional communication culture among future social workers by means of interactive teaching methods]: 
dys. kand. ped. nauk: 13.00.04 „Teoriia i metodyka profesiinoi osvity”. Nats. aviats. un-t. Kyiv, 200.

Vodiana, O.V. (2016). Profesiina pidhotovka maibutnikh sotsialnykh pratsivnykiv do sotsialnoho suprovodu simei, v yakykh perebuvaiut dity pid opikoiu [Professional training of future social workers for social support of families in which children are under guardianship]: avtoref. dys. na zdob. nauk. stup. kand. ped. nauk: spets. 13.00 .04 „Teoriia i metodyka profesiinoi osvity”, Ternopilskyi nats. ped. un-t im. V. Hnatiuka. Ternopil, 20.

Vozniuk, O.M. (2014). Psykholohichni umovy zastosuvannia aktyvnykh metodiv navchannia $\mathrm{v}$ protsesi pidhotovky sotsialnykh pratsivnykiv [Psychological conditions for the use of active teaching methods in the process of training social workers]: avtoref. dys. na zdob. nauk. stup. kand. psykh. nauk: spets. 19.00.07 „Pedahohichna ta vikova psykholohiia”. In-t psykholohii im. H.S. Kostiuka NAPN Ukrainy. Kyiv, 20.

Zakon Ukrainy „Pro vyshchu osvitu” (2014) [Law of Ukraine “On Higher Education”]. Mode of access: zakon.rada.gov.ua/laws/show/1556-18 (access: 10.07.2018).

Zhovnirchyk, Ya. (2005). Formuvannia samodostatnikh terytorialnykh hromad i stratehiia yikh ekonomichnoho samorozvytku [Formation of self-sufficient territorial communities and strategy of their economic self-development]. Universytetski naukovi zapysky Khmelnytskoho Universytety Manegmentu i Prawa [Scientific Journals of Khmelnytskyi University of Management and Law], 1-2.

Zolotareva, T., Mynyhalyeva, M. (2001). Osnovy psykholohycheskoi samopomoshchy sotsyalnoho rabotnyka [Basics of Psychological Self-Help of a Social Worker: A Manual]. Moskva: MHSU.

Zvierieva, I.D. (1998). Teoriia i praktyka sotsialno-pedahohichnoi roboty $z$ ditmy ta moloddiu v Ukraini [Theory and practice of social pedagogical work with children and youth in Ukraine]: dys. doktora ped. nauk : 13.00 .05 „Sotsialna pedahohika”. Nats. ped. un-t im. M.P. Drahomanova. Kyiv, 390. 